\title{
Survival after profound hypocalcaemia with tetany complicating severe haemorrhagic acute pancreatitis
}

\author{
Peter A. Jones
}

Surgical Unit, Westminster Hospital, London SWI, UK.

Summary: A patient is reported who developed severe haemorrhagic pancreatitis, without hyperamylasemia, which was complicated by gross hypocalcaemia presenting as tetany. Tetany is very uncommon in acute pancreatitis and is a grave prognostic indicator, recovery being exceptionally rare. The mechanisms responsible for disordered calcium homeostasis associated with acute pancreatitis are reviewed. CT scanning was an important feature of this patient's management and its role in severe pancreatitis is discussed.

\section{Introduction}

Calcium metabolism may be seriously disturbed in acute pancreatitis and has been reported in $3.30 \%$ of cases (Kasper \& Sommer, 1976). A serum calcium below $2.0 \mathrm{mmol} / \mathrm{l}$ is one of Ransom's early signs which correlates with severe illness or death (Ransom, 1982). Similarly, Jacobs et al. (1977) report significantly higher mortality rates in patients with hypocalcaemia. Tetany due to hypocalaemia is very uncommon and bears an extremely poor prognosis (Durr, 1979). Pollock (1959) reported six cases and Jacobs et al. (1977) added two further cases, all of whom died. A patient is therefore reported whose presenting complaint was tetany, whose calcium on admission was $1.07 \mathrm{mmol} / 1$ and who survived.

\section{Case history}

A 39 year old bankrupt company director, was admitted to Westminster Hospital on New Year's Eve complaining of painful cramps in his hands and abdominal distension. Four days earlier the patient had developed severe central abdominal pain associated with vomiting which lasted two days. Before admission the patient noticed he was passing little urine. Since the liquidation of his business six months earlier he had consistently consumed approximately one bottle of spirits daily. He was pyrexial $\left(37.5^{\circ} \mathrm{C}\right)$, had a sinus tachycardia of $120 / \mathrm{min}$, was hypotensive, blood pressure $100 / 60 \mathrm{~mm} \mathrm{Hg}$, and had tachypnoea $22 / \mathrm{min}$. Chvostek's sign and Trousseau's sign were both elicited. The abdomen was distended

P.A. Jones, M.S., F.R.C.S.

Present address: Maidstone Hospital, Hermitage Lane, Maidstone, Kent ME16 9QQ.

Accepted: 13 December 1983 and generally mildly tender, without guarding. Bowel sounds were absent. Investigations on admission were: Haemoglobin $15.9 \mathrm{~g} / \mathrm{dl}$, white cell count $7.4 \times 10^{9} / 1$, plasma urea $11.3 \mathrm{mmol} / 1$, sodium $133 \mathrm{mmol} / 1$, potassium $3.8 \mathrm{mmol} / \mathrm{l}$, bicarbonate $23 \mathrm{mmol} / \mathrm{l}$, total protein 70 , albumin $32 \mathrm{~g} / \mathrm{l}$, calcium $1.07 \mathrm{mmol} / \mathrm{l}$, phosphate $1.12 \mathrm{mmol} / 1$. Chest X-ray was normal, abdominal $\mathrm{x}$ rays showed a central loop of slightly dilated jejunum. Serum amylase was $45 \mathrm{IU} / \mathrm{l}$ (phadebas). Blood gases pH 7.39, $\mathrm{PCO}_{2} 4.31 \mathrm{kPa}, \mathrm{PO}_{2} 8.38 \mathrm{kPa}$. Despite the normal amylase a diagnosis of acute pancreatitis was made and this was confirmed by computed tomographic (CT) scan (Figure 1). Paracentesis revealed typical 'prune-juice' fluid, the amylase of which was not raised. Treatment consisted of intravenous fluids, broad spectrum antibiotics, oxygen, intravenous calcium, and a single peritoneal lavage. Serial CT scans showed diffuse pancreatic necrosis but no abscess or pseudo-cyst formation. Therefore, despite developing a swinging pyrexia, surgery was avoided. Daily plasma calcium levels $(\mathrm{mmol} / \mathrm{l})$ with corresponding serum albumin $(\mathrm{g} / \mathrm{l})$ were $1.07(31), 0.94(26), 0.94(22)$, $1.04(26), \quad 1.2(24), \quad 1.35(24), \quad 1.58(20), \quad 1.69(20)$, $1.80(23), 1.85(21), 1.95(22), 2.02(22), 2.29(26)$ and $2.23(25)$. The patient developed a persistent ileus and was parenterally fed for $\mathbf{1 0}$ days after which normal bowel function returned. The pyrexia resolved and the patient was discharged home three weeks after admission. He has remained well.

\section{Discussion}

This case demonstrates several important aspects in the management of acute pancreatitis. It confirms again that a normal serum amylase level is compatible with a diagnosis of acute pancreatitis. Perhaps the 


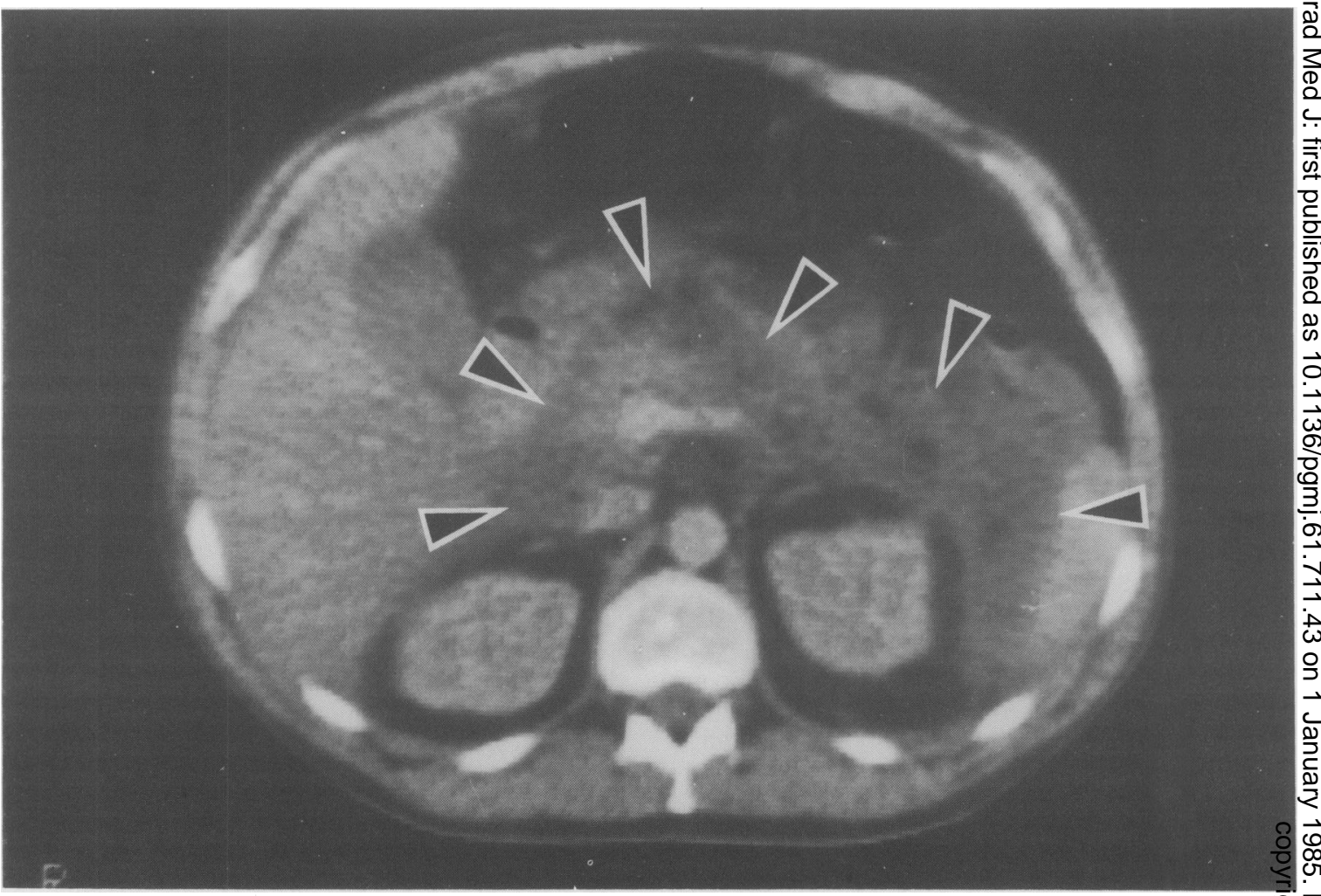

Figure 1 CT scan at $L_{1} / L_{2}$ level showing oedema of the pancreas with areas of low attentuation within the gland indicating necrotizing pancreatitis. Extra-pancreatic inflammation has thickened the tissues of the anterior and posterior para-renal spaces.

serum amylase was not raised in this patient because of his late presentation, although normal amylase activities are not infrequently found in patients in whom severe acute pancreatitis is proved at laparotomy or autopsy (Durr, 1979).

CT scan confirmed the diagnosis of acute necrotizing pancreatitis which would otherwise have been difficult to substantiate, despite the deranged renal and respiratory function and profound hypocalcaemia. Serial scans during the days of swinging pyrexia excluded a pancreatic abscess, avoiding the possibility of unnecessary exploratory laparotomy. The role of CT scans in the diagnosis and monitoring of acute necrotizing pancreatitis has been previously described and is used routinely in some centres (Aeberhard et al., 1982). The patient reported also showed the value of aggressive non-operative management in patients with grave prognostic indicators. The degree of hypocalcaemia, as low as $0.94 \mathrm{mmol} / 1$ even after calcium replacement, is most uncommon, and tetany as a presenting symptom must be very rare. Apparently, even more rare is to survive acute pan- creatitis complicated by tetany (Durr, 1979).

The precise mechanism of the disordered calcium homeostasis complicating acute pancreatitis is imperfectly understood but is probably multifactorial. Some reduction in total serum calcium may occur on the basis of hypoalbuminaemia. A fall of serum albumin due to protein loss, largely in exudates, is claimed by some to contribute substantially to the recorded lower calcium levels (Imrie et al., 1978). Our patient's albumin was initially normal but later fell considerably. The amount of ionized calcium deposited and sequestrated in areas of fat necrosis by saponification is considerable (Storck \& Bjorntorp, 1971). Normally, secretion of parathyroid hormone should maintain $\sigma$ calcium homeostasis and the hypocalcaemia of severe $N$ acute pancreatitis has been explained on the basis of $N$ inadequate parathyroid hormone release (Robertson et al., 1976) or by the possible refractoriness of bone to parathyroid hormone (Weir et al., 1975).

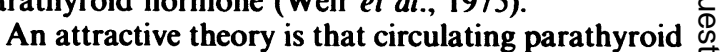
hormone is hydrolysed by proteolytic enzymes within the blood stream; $\alpha_{2}$ macroglobulin bound trypsin, for 
example, rapidly abolishes the bioactivity of human parathyroid hormone in vitro (Hermon-Taylor et al., 1981). Furthermore leupeptin, a proteinase inhibitor of microbial origin, which inhibits both free and bound trypsin, significantly decreased the fall in calcium levels of rats with experimental acute haemorrhagic pancreatitis (Jones et al., 1982). Other suggested factors include raised levels of glucagon and calcitonin which could inhibit resorption of bone (Condon et al., 1975) and hypomagnesaemia (Estep et al., 1969). Hypomagnesaemia complicating acute pan-

\section{References}

AEBERHARD, P., VOCK, P. \& KELLER, A. (1982). Contribution of computed tomography in the management of acute necrotising pancreatitis In Controversies in Acute Pancreatitis, Hollender, L.F. (ed.) p.95, Springer-Verlag: Berlin.

BANKS, P.A. (1979). In Pancreatitis (Topics in Gastroenterology), chapter 2, p. 12, Plenum Publishing Corporation: New York.

CONDON, J.R., IVES, D., KNIGHT, M.J. \& DAY, J. (1975). The aetiology of hypocalcaemia in acute pancreatitis. British Journal of Surgery, 62, 115.

DURR, G.H-K. (1979). In The Exocrine Pancreas, Howat H.T. and Sarles, H., (eds.) p. 352, Saunders: London.

ESTEP, H., SHAW, W.A., WATLINGTON, C., HOBE, R., HOLLAND, W. \& TUCKER, ST.G. (1969). Hypocalcaemia due to hypomagnesemia and reversible parathyroid unresponsiveness. Journal of British Endocrinology, 29, 842.

HERMON-TAYLOR, J., MAGEE, A.I., GRANT, D.A.W., JONES, P.A., MARSHALL, C.E. \& DUNHAM, J. (1981). Cleavage of peptide hormones by $\beta_{2}$ macroglobulin-trypsin complex and its relation to the pathogenesis and chemotherapy of acute pancreatitis. Clinica Chemica Acta, 109, 203.

HERSH, T. \& SIDDIQUE, D.A. (1973) Magnesium and the pancreas. American Journal of Clinical Nutrition, 26, 362.

IMRIE, C.N., ALLAM, B.F., JERGUSON, J.C. \& BLUMGART, L.H. (1978). Hypoalbuminaemia: the common cause of hypocalcaemia in acute pancreatitis. Annals of the Royal College of Surgeons, 59, 135. creatitis is also of diverse aetiology (Hersh and Siddique, 1973) but the mechanism by which a decrease in serum magnesium prevents restoration of normocalcaemia has not been fully elucidated (Banks, 1979).

\section{Acknowledgements}

I am most grateful to Dr R. Zeegen and Professor Harold Ellis for allowing me to report their patient.

JACOBS, M.L., DUGGETT, W.M., CIVETTA. J.M., VASSA, M., LAWSON, D.W., WARSHAW, A.L., NARDI, G.L. \& BARTLETT, M.K. (1977). Acute pancreatitis: analysis of factors influencing survival. Annals of Surgery, 185(1), 43.

JONES, P.A., GRANT, D.A.W. \& HERMON-TAYLOR, J. (1982). Single agent antiproteinase chemotherapy of experimental acute pancreatitis using the low molecular weight oligopeptide aldehyde leupeptin. Annals of the Royal College of Surgeons, 64, 420.

KASPER, H. \& SOMMER, H. (1976). Klinik der akuten pankreatitis. In Handbuch der Inneren Medizin Band 3, Teil 6, Pankreas 5 Auflage, Forell, M.M., (ed.) Springer, Berlin, Heidelberg, New York.

POLLOCK, A.V. (1959). Acute pancreatitis, analysis of 100 patients. British Medical Journal, i, 6.

RANSOM, J.H.C. (1982). Objective prognostic evaluation of patients with acute pancreatitis. In Controversies in Acute Pancreatitis, Hollender, L.F. (ed.) p. 112, Springer-Verlag: Berlin.

ROBERTSON, G.M. JR., MOORE, E.W., SWITZ, D.M., SIZEMORE, G.W. \& ESTEP, H.L. (1976). Inadequate parathyroid response in acute pancreatitis. New England Journal of Medicine, 294, 512.

STORCK, G. \& BJORNTORP, P. (1971). Chemical composition of fat necrosis in experimental pancreatitis in the rat. Scandinavian Journal of Gastroenterology, 6, 225.

WEIR, G.C., LESSER, P.B., DROP, L.J., FISCHER, J.E. \& WARSHAW, A.L. (1975). The hypocalcaemia of acute pancreatitis. Annals of Internal Medicine, 83, 185. 